\title{
The Effect of Cash Conversion Cycle and Chief Executive Officer Power on Financial Distress and Leverage an Intervening Variable
}

\author{
Fitri Indah Sari ${ }^{1}$, R. A. Damayanti ${ }^{2}$, Andi Kusumawati ${ }^{3}$ \\ ${ }^{1,2,3}$ Hasanuddin University, Makassar, Indonesia \\ Corresponding Author: Fitri Indah Sari
}

\begin{abstract}
This study aims to determine and analyze (1) the effect of the cash conversion cycle on financial distress, (2) the effect of chief executive officer power on financial distress, (3) the effect of the cash conversion cycle on leverage, (4) the effect of chief executive officer power on leverage (5) Effect of cash conversion cycle on leverage (6) Effect of cash conversion cycle on financial distress through leverage (7) Effect of chief executive officer power on financial distress through leverage.

This research is a type of quantitative research. In this study using agency theory and stakeholder theory. The population in this study were all manufacturing companies listed on the Indonesia Stock Exchange (IDX) in 2016-2020. The sample determination in this study used purposive sampling with a sample size of 80 . The research data is secondary data accessed through www.idx.co.id. The results showed that the cash conversion cycle had a positive and significant effect on financial distress. Chief executive officer power has a positive and significant effect on financial distress. Cash conversion cycle has a positive and significant effect on leverage. Cash conversion cycle has a negative effect on leverage. Cash conversion cycle has a positive effect on financial distress through leverage. Chief executive officer power has a negative effect on financial distress through leverage.
\end{abstract}

Keywords: Cash Conversion Cycle, Chief Executive Officer Power, Financial Distress, Leverage.

\section{PRELIMINARY}

The development of the business world in the era of globalization as well as fierce competition encourages companies to strengthen their management fundamentals in order to be able to survive and remain in the competition. Efforts for companies to anticipate this competition, companies are required to always develop innovation, improve overall performance and develop business in order to avoid conditions of loss and bankruptcy. The inability of a company to compete with other companies does not rule out the possibility that the company will experience a decline in profits and the company will be in a state of bankruptcy (Venusita and Wijayanti, 2019). The company's inability to manage and maintain stable financial performance causes the company to experience operational losses and net losses for the current year (Lubis and Patrisia, 2019). This will have an impact on the company's inability to pay its financial obligations, this is an indication that the company's finances are in an unhealthy condition or experiencing financial distress (Venusita and Wijayanti, 2019).

Financial distress will occur in a company before it goes bankrupt (Susanti et al., 2020). Bankruptcy of a company often occurs in the business world, both influenced by internal and external parties. This event occurred because the company was not able to handle the company properly until the company finally 
experienced a business failure, this is what causes the company to experience a condition of declining company profits to be minus (total revenue is less than the company's total expenses) (Muhammad et al., 2018).

To avoid the occurrence of financial distress, companies must be able to predict financial distress early by collecting information related to financial distress. There are three benefits of financial distress information that occurs in companies, namely: it can accelerate company management actions to prevent problems before bankruptcy occurs, management can immediately take merger or takeover actions so that companies can be better able to pay debts and can manage the company better, and can also provide early warning signs of bankruptcy in the future (Lubis and Patrisia, 2019). There are several phenomena, where companies are delisted from the IDX due to the company's inability to fulfill its obligations. We can see the first phenomenon in 2017, where the Indonesia Stock Exchange (IDX) deleted the listing of PT. Citra Maharlika Nusantara Corpora Tbk (CPGT) which became effective on 19 October 2017. The Indonesia Stock Exchange had to be delisted because the company was declared bankrupt on 28 April 2017 by the Central Jakarta Commercial Court and CPGT's bankrupt assets were in a state of bankruptcy due to the confiscation of assets from vehicles and heavy equipment owned by the company by Tax. PT. Dwi Aneka Jaya Kemasindo (DAJK), a company engaged in manufacturing, was declared bankrupt by the Central Jakarta District Court on November 23, 2017 after a lawsuit from PT. Bank Mandiri as a creditor was granted (Muda and Tarmizi, 2019). The picture above shows that the financial distress experienced by a company begins with the company's inability to meet its obligations when they fall due or shows a high level of company leverage.

Leverage is the ratio between total debt and equity. Leverage reflects the company's ability to pay all its obligations, both in the form of short and long term, debt of companies with a high level of leverage will have greater financial risk than companies with low levels of leverage (Fujianti \& Satria, 2020). The factor that triggers companies to do leverage is the cash conversion cycle. According to Telly et al. (2019) Cash conversion cycle is one of the measurements of WCM (working capital management) which is the period of time required by the company from the time the purchased raw materials are paid to the accounts receivable from the sale of collectible goods. The decision to do leverage, of course, cannot be separated from the role of the chief executive officer or in Indonesia better known as the main director or president director, which is the highest position in the company's executive ranks. Harper and Sun, (2019) found that stronger CEOs use less debt financing, and the impact of changes in capital structure on firm performance is more negative for firms with stronger CEOs.

\section{LITERATURE REVIEW Agency Theory}

Agency theory was first coined by Jensen and Maeckling in 1976. Jensen stated that agency relationships occur when one or more people (principals) hire another person (agent) to provide a service and then delegate decision-making authority. Agency model is considered to be one of the oldest theories in the literature where agency theory addresses surface problems in companies because of the separation between owners and managers as a form of reducing problems. This theory helps in implementing various mechanisms to control the actions of agents in the company. Agency conflicts arise because of differences in interests between agents and principals (Panda and Leepsa, 2017).

\section{Stakeholder Theory}

The definition of stakeholder according to Freeman (1984) is a theory that describes which parties the company is responsible for. Stakeholder theory is a 
theory that explains the existence of the company in carrying out its activities to contribute to its stakeholders. Stakeholders are parties with an interest in the company that can influence or can be influenced by the company's activities. This theoretical view suggests that companies will choose to present voluntary statements of information regarding intellectual, social and environmental performance beyond the mandatory reporting requirements of an institution, in order to meet the real expectations and perceptions of stakeholders (Virgiawan and Kurniawan, 2019). This theory also states that corporate managers will try to obtain added value which will then be distributed to all stakeholders. The benefits of this theory focus on the interests of stakeholders, that all business activities of the company's operations are for the benefit of stakeholders. Stakeholder theory states that all stakeholders have the right to be given information about the company's activities, including the financial activities of the company.

\section{Financial Distress}

Financial distress is a condition where a company is facing financial difficulties and conditions that occurred before the company actually went bankrupt (Venusita and Nur Wijayanti, 2019). Financial distress is a condition that shows the stage of a company's financial decline that occurred before the liquidation occurred (Patrisia and Lubis, 2019). Financial distress is a relationship between short-term and insolvable liquidity difficulties which can be seen from the composition of cash flows and the strategic financial statements of the company (Putri \& Rachmawati, 2018). The criteria for financial distress are in the form of a company condition that is technically unable to pay its debts even though it has a positive net worth, in simple terms it can be said that current assets are not sufficient to pay current (short-term) debt. The second criterion is the market value shown by the company, where the value of the company's assets is lower than the debt it has so that it is in a negative wealth value position, technically the company is in a state of bankruptcy so that it can be said that the company has experienced business failure (Darmansyah, 2016).

\section{Cash Conversion Cycle}

Cash conversion cycle is a comprehensive performance measure used to assess the company's ability to manage working capital (Telly et al., 2019). Cash conversion cycle is a ratio used to measure how long the company can collect cash from the company's operating results which will ultimately affect the amount of funds needed to be stored in current assets (Ramdani and Rahardjo, 2017). Companies in managing their cash using a cash conversion cycle require or formulate steps consisting of: conversion period or inventory turnover, receivables receipt period, and debt suspension period (Telly et al., 2019).

\section{Chief Executive Officer (CEO) Power}

The chief executive officer is the highest position in a company and also has the task of leading a company and is responsible for the stability of the company. The chief executive officer potentially has the power to influence or determine the strategy and performance of the company. The presence of a powerful CEO is very important and useful to reduce conflict, increase trust between directors and authorize decision making (Sudana and Aristina, 2017).

\section{Leverage}

Leverage occurs when a company uses sources of funds that generate fixed expenses. The purpose of using leverage is to increase returns to common stockholders. Horne and Wachowicz (2007: 1993) in Lestari and Nuzula (2017) say that favorable leverage occurs if a company can generate revenue received from the use of. 


\section{Hypothesis}

Based on the formulation of the problem and the framework that has been put forward, the hypotheses in this study are:

1. Cash conversion cycle has a positive effect on financial distress.

2. Chief executive officer (CEO) power has a positive effect on financial distress

3. Cash conversion cycle has a positive effect on leverage

4. Chief Executive Officer (CEO) power has a positive effect on leverage

5. Leverage has a positive effect on financial distress

6. Cash conversion cycle through leverage has a positive effect on financial distress.

7. Chief executive officer (CEO) power through leverage has a positive effect on financial distress.

\section{RESEARCH METHODS}

A study must be well designed or designed. Research design is a research structure that directs processes and results that are efficient, effective, valid and objective. This research needs to be designed in general by determining its characteristics which can be explained as follows. The research is located at the Indonesian Stock Exchange Representative Office, Makassar City, Jl. DR. Ratulangi No. 124 by downloading or accessing financial report data and other data from the official website of the Indonesia Stock Exchange (IDX) which provides audited financial reports through the official website www.idx.co.id. The population of this study is all Manufacturing Companies listed on the Indonesia Stock Exchange (IDX) 20162020. The sample selection technique was carried out using the non-probability side, namely taking the purposive sampling method with the aim of getting a representative sample in accordance with the specified criteria. The number of financial statements used as samples in this study amounted to 80 financial statements originating from 16 sample companies listed on the IDX during period of 5 years, namely 2016-2020. The type of data used in this study is secondary data in the form of quantitative data which includes data on the financial statements of manufacturing companies. This research uses SPSS (Statistical Package For the Social Science) 21 and Microsoft Excel 2010 for data processing. The analysis and tests carried out in this study were descriptive statistics, classical assumption test (normality test, multicollinearity test, heteroscedasticity test, and autocorrelation test), hypothesis testing and Sobel test.

\section{RESEARCH RESULT}

\section{Hypothesis testing}

Based on the table from the results of data processing above, the following regression equation is obtained:

\begin{tabular}{|c|c|c|c|c|c|c|}
\hline \multirow{3}{*}{\multicolumn{2}{|c|}{ Model }} & \multirow{2}{*}{\multicolumn{2}{|c|}{ Unstandardized Coefficients }} & \multirow{3}{*}{$\begin{array}{l}\text { Standardized Coefficients } \\
\text { Beta }\end{array}$} & \multirow{3}{*}{$\mathbf{t}$} & \multirow{3}{*}{ Sig. } \\
\hline & & & & & & \\
\hline & & B & Std. Error & & & \\
\hline \multirow[t]{3}{*}{1} & (Constant) & ,771 &, 410 & & 1,882 &, 064 \\
\hline & $\mathrm{CCC}$ & ,007 &, 002 & ,387 & 3,690 &, 000 \\
\hline & CEO &,- 007 &, 008 &,- 095 &,- 902 & ,370 \\
\hline
\end{tabular}

$\mathrm{Y}=0.007 \mathrm{X} 1-0.257 \mathrm{X} 2+0.845 \mathrm{e} 1 \ldots(1)$

The $\mathrm{t}$-value of the variable $\mathrm{X} 1=$ 3.690, and the t-table is 1.99167. The significance value of the variable $\mathrm{X} 1=$ 0.000 thus it can be concluded that the regression model 1 variable $\mathrm{X} 1$ has a positive and significant effect on Y1.
The value of $\mathrm{t}$-count variable $\mathrm{X} 2=$ 0.902 and t-table 1.99167. The significance value of the $\mathrm{X} 2$ variable $=0.370$. Thus, it can be concluded that the regression model of the X2 variable has a negative and insignificant effect on Y1. 
Fitri Indah Sari et.al. The effect of cash conversion cycle and chief executive officer power on financial distress and leverage an intervening variable.

\begin{tabular}{|l|l|l|l|l|}
\hline \multicolumn{5}{|c|}{ Path Coefficient Table Model I } \\
\hline Model & R & R Square & Adjusted R Square & Std. Error of the Estimate \\
\hline 1 &, $394^{\mathrm{a}}$ &, 155 &, 133 & 2,40859 \\
\hline \multicolumn{4}{|l|}{ |redictors: (Constant), CEO, CCC } \\
\hline
\end{tabular}

The table above shows the correlation coefficient $(\mathrm{R})$ of 0.155 . This shows that the effect of $\mathrm{X} 1$ and $\mathrm{X} 2$ on $\mathrm{Y} 1$ is $15.5 \%$ while the remaining $84.5 \%$ is the

contribution of other variables not included in the study. Meanwhile, the value of e1 is obtained by the formula $\mathrm{e} 1=\sqrt{ }(1-$ $0.155)=0.845$.

\begin{tabular}{|c|c|c|c|c|c|c|}
\hline \multicolumn{7}{|c|}{ Model II Path Analysis Table } \\
\hline \multirow{2}{*}{\multicolumn{2}{|c|}{ Model }} & \multicolumn{2}{|c|}{ Unstandardized Coefficients } & \multirow{2}{*}{$\begin{array}{l}\text { Standardized Coefficients } \\
\text { Beta }\end{array}$} & \multirow[t]{2}{*}{$\mathbf{t}$} & \multirow[t]{2}{*}{ Sig. } \\
\hline & & B & Std. Error & & & \\
\hline \multirow[t]{4}{*}{1} & (Constant) & ,239 & 202 & & 1,186 & 239 \\
\hline & $\mathrm{CCC}$ &, 002 &, 001 &, 219 & 2,035 &, 045 \\
\hline & CEO &, 012 & ,004 &, 302 & 3,030 &, 003 \\
\hline & Leverage &, 140 &, 055 &, 275 & 2,548 &, 013 \\
\hline
\end{tabular}

Based on the table above from the results of data processing, the following regression equation is obtained:

$\mathrm{Y}=0.002 \mathrm{X} 1-0.12+0.576 \mathrm{Y} 1+0.746 \mathrm{e} 2 \ldots$

(2)

a. in the table, it is known that the t-count for the variable $\mathrm{X} 1=2.035$ and the $\mathrm{t}$ table is 1.99125 . The significance value of the variable $\mathrm{X} 1=0.045$ is smaller than 0.05 , with this it can be concluded that $\mathrm{X} 1$ has a positive and significant effect on $\mathrm{Y}$. b. $\mathrm{T}$ count variable $\mathrm{X} 2=3.030$ and t-table is 1.99125 . The significance value of the variable $\mathrm{X} 2=0.003$ is smaller than 0.05 with this it can be concluded that $\mathrm{X} 2$ has a positive and significant effect on $\mathrm{Y}$

c. T count variable $\mathrm{Y}=2.548$ and $\mathrm{t}$-table is 1.99125. The significance value of the variable $\mathrm{Y}=0.013$ is smaller than 0.05 , it is hereby concluded that $\mathrm{Z}$ has a positive and significant effect on $\mathrm{Y}$.

\begin{tabular}{|l|l|l|l|l|}
\hline \multicolumn{4}{|c|}{ Parth Coeficient Test II } \\
\hline Model & R & R Square & Adjusted R Square & Std. Error of the Estimate \\
\hline 1 &, $504^{\mathrm{a}}$ &, 254 &, 225 & 1,15955 \\
\hline a. Predictors: (Constant), Leverage, CEO, CCC \\
\hline
\end{tabular}

The table above shows the value of the relation coefficient $(\mathrm{R})$ of 0.254 . This shows that the effect of $\mathrm{X} 1, \mathrm{X} 2$, and $\mathrm{Y} 1$ on $\mathrm{Z}$ is $25.4 \%$ while the remaining $74.6 \%$ is a contribution from other variables not included in the study. Meanwhile, the value of e2 is obtained by the formula e $1=\sqrt{ }(1-$ $0.254)=0.746$.

\section{Sobel Test}

Sobel Test Table I

\begin{tabular}{|l|l|l|l|}
\hline \multicolumn{4}{|c|}{ Cash conversion cycle - Leverage - Financial Distress } \\
\hline A & B & Sa & Sb \\
\hline 0,007 & 0,140 & 0,002 & 0,055 \\
\hline
\end{tabular}

Based on the results of the above calculation, the t-count value of 2.00409 is greater than the t-table value of 1.99167, it can be concluded that there is a mediation effect. This shows that $\mathrm{X} 1$ through $\mathrm{Z}$ indirectly affects $Y$. Thus the hypothesis is accepted.

Sobel Test Table II

\begin{tabular}{|l|l|l|l|}
\hline \multicolumn{4}{|c|}{ Chief Executive Officer Power - Leverage - Financial Distress } \\
\hline A & B & Sa & Sb \\
\hline$-0,007$ & 0,140 & 0,002 & 0,055 \\
\hline
\end{tabular}

Based on the results of the above calculation, the t-value -0.77593 is smaller than the t-table value of 1.99167 , it can be concluded that there is no mediation effect. This shows that indirectly $\mathrm{X} 2$ through $\mathrm{Z}$ has no effect on Y. Thus the hypothesis is rejected.

\section{CONCLUSION}

1. Cash conversion cycle has a positive and significant effect on financial distress. 
The results of testing the hypothesis can be interpreted that the longer the period of time required by the company in converting its cash will cause the company to get closer to financial distress.

2. Chief executive officer (CEO) power has a positive and significant effect on financial distress. This means that the greater the power the CEO has, the greater the possibility of financial distress.

3. Cash conversion cycle has a positive and significant effect on leverage. This means that the longer the cash conversion cycle, the higher the company's leverage.

4. Chief executive officer (CEO) power has a negative effect on leverage. This means that the greater the power possessed by the CEO, the lower the level of company leverage.

5. Cash conversion cycle has a positive and significant effect on financial distress. This means that the longer the cash conversion cycle period, the greater the occurrence of financial distress.

6. Cash conversion cycle has a positive effect on financial distress through leverage. This means that leverage can be a link between the cash conversion cycle and leverage.

7. Chief executive officer power has a negative effect on financial distress through leverage. This means that leverage cannot be a link between chief executive officer power and financial distress.

Acknowledgement: None

\section{Conflict of Interest: None}

\section{Source of Funding: None}

\section{REFERENCES}

1. Darmansyah. (2016). Pengaruh Financial Distress Terhadap Kualitas Laporan Keuangan Dengan Pemediasi Prudence. Jurnal Akuntansi Dan Keuangan Indonesia, 12(2), Article on
Press.
http://ejournal.upi.edu/index.php/JRAK/arti cle/view/6612/4490\%0Ahttp://jaki.ui.ac.id/i ndex.php/home/article/view/581\%0Ahttp://l inkinghub.elsevier.com/retrieve/pii/S221256 7114008016

2. Dwi Kusuma Ramdani, \& Rahardjo, S. T. (2017). Departemen Manajemen Fakultas Ekonomika dan Bisnis Universitas Diponegoro Jl. Prof. Soedharto SH Tembalang, Semarang 50275, Phone: +622476486851 . Diponegoro Journal Of Management, 6, 1-11.

3. Fujianti, L., \& Satria, I. (2020). Firm size, profitability, leverage as determinants of audit report lag: Evidence from Indonesia. International Journal of Financial Research, 11(2). https://doi.org/10.5430/ijfr.v11n2p61

4. Harper, J., \& Sun, L. (2019). CEO power and corporate social responsibility. American Journal of Business, 34(2), 93115. https://doi.org/10.1108/ajb-10-20180058

5. Lestari, Y., \& Nuzula, N. (2017). Analisis Pengaruh Financial Leverage Dan Operating Leverage Terhadap Profitabilitas Perusahaan (Studi Pada Perusahaan Sektor Keuangan yang Terdaftar di Bursa Efek Indonesia Periode 2012-2015). Jurnal Administrasi Bisnis S1 Universitas Brawijaya, 46(1), 1-10.

6. Lubis, N. H., \& Patrisia, D. (2019). Pengaruh Activity Ratio, Leverage dan Firm Growth Terhadap Financial Distress ( Studi Empiris pada Perusahaan Manufaktur yang Terdaftar di BEI Periode 2013-2017 ). 01(2013), 173-182.

7. Muda, I., \& Tarmizi, H. (n.d.). The Effect Of Corporate Governance Mechanism, Leverage, And Profitability On Financial Distress With Liquidity As Moderating Variables In Manufacture Companies Listed On Indonesia Stock Exchange (Idx). In International Journal Public Budgeting, Accounting and Finance (Vol. 4).

8. Muhammad, S., Sadalia, I., \& Fachrudin, K. A. (2018). An Analysis on the Influence of Fundamental Factors, Intellectual Capital and Corporate Governance on Bankruptcy Prediction Using Springate (S- Score) Method in the Mining Companies Listed on the Indonesian Stock Exchange. International Journal of Research and Review, 5(11), 85-97.

9. Panda, B., \& Leepsa, N. M. (2017). Agency theory: Review of theory and evidence on 
Fitri Indah Sari et.al. The effect of cash conversion cycle and chief executive officer power on financial distress and leverage an intervening variable.

problems and perspectives. Indian Journal of Corporate Governance, 10(1), 74-95. https://doi.org/10.1177/0974686217701467

10. Putri, B. N. L., \& Rachmawati, S. (2018). Analisis Financial Distress dan Free Cash Flow dengan Proporsi Dewan Komisaris Independen sebagai Variabel Moderasi Terhadap Manajemen Laba. Jurnal Keuangan Dan Perbankan, 14(2), 54-61.

11. Sudana, I. M., \& Aristina, N. P. N. (2017). Chief Executive Officer (Ceo) Power, Ceo Keluarga, Dan Nilai Ipo Premium Perusahaan Keluarga Di Indonesia. Jurnal Akuntansi, $\quad 21(2), \quad 219$. https://doi.org/10.24912/ja.v21i2.196

12. Susanti, N., Latifa, I., \& Sunarsi, D. (n.d.). The Effects of Profitability, Leverage, and Liquidity on Financial Distress on Retail Companies Listed on Indonesian Stock Exchange. http://ojs.unm.ac.id/iap

13. Telly, B. R., Ansori, M., Studi, P., Manajerial, A., Batam, P. N., \& Centre, B. (2019). Effect Of Size and Cash Conversion Cycle On Company Profitability. Journal Of Applied Managerial Accounting Vol. 3 No. March 2019. 3(1), 155-165.
14. Venusita, L., \& Nur Wijayanti, M. (2019). Turnaround Strategy of Financially Distressed Company: Empirical Study of Manufacturing Company Listed on Indonesia Stock Exchange. KnE Social Sciences, 3(11), 21. https://doi.org/10.18502/kss.v3i11.3996

15. Virgiawan, G. A. B. A., \& Kurniawan, P. S. (2019). Pengaruh Pengungkapan Intellectual Capital, Pengukuran Value Added Intellectual Capital (Vaic) Struktur Kepemilikan, Dan Cost Of Equity Capital Terhadap Kapitalisasi Pasar Perusahaan (Studi Perusahaan Perbankan Pada Bursa Efek Indonesia Periode 2014-2017). JIMAT (Jurnal Ilmiah Mahasiswa Akuntansi) Undiksha, 9(3), 110-121.

How to cite this article: Sari FI, Damayanti RA, Kusumawati A. The effect of cash conversion cycle and chief executive officer power on financial distress and leverage an intervening variable. International Journal of Research and Review. 2021; 8(7): 337-343. DOI: https://doi. org/10.52403/ijrr.20210747 